\title{
Protein and fat modify the glycaemic and insulinaemic responses to a mashed potato-based meal
}

\author{
Katja A. Hätönen $^{1 *}$, Jarmo Virtamo ${ }^{2}$, Johan G. Eriksson ${ }^{2,3,4,5,6}$, Harri K. Sinkko ${ }^{1}$, Jouko E. Sundvall ${ }^{2}$ \\ and Liisa M. Valsta ${ }^{1}$ \\ ${ }^{1}$ Department of Lifestyles and Participation, National Institute for Health and Welfare, Mannerheimintie 166, FI-O0271 \\ Helsinki, Finland \\ ${ }^{2}$ Department of Chronic Disease Prevention, National Institute for Health and Welfare, Helsinki, Finland \\ ${ }^{3}$ Department of General Practice and Primary Health Care, University of Helsinki, Helsinki, Finland \\ ${ }^{4}$ Vaasa Central Hospital, Vaasa, Finland \\ ${ }^{5}$ Unit of General Practice, Helsinki University Central Hospital, Helsinki, Finland \\ ${ }^{6}$ Folkhälsan Research Centre, Helsinki, Finland
}

(Received 17 March 2010 - Revised 19 October 2010 - Accepted 20 December 2010 - First published online 22 February 2011)

\begin{abstract}
Potatoes, especially mashed potatoes, are known to result in high glycaemic and insulinaemic responses. However, in most meals, potatoes are accompanied by other foods. The objective of the present study was to investigate how glycaemic and insulinaemic responses to a mashed potato meal changed when a high-fat food (rapeseed oil), a high-protein food (chicken breast) and/or salad were added to the meal. Healthy subjects ( $n$ 11) ingested the test meals once and the reference food (glucose solution) twice in a random order at 1-week intervals. Capillary blood samples were then drawn for $2 \mathrm{~h}$, and glucose and insulin were analysed. The $2 \mathrm{~h}$ glycaemic responses to six mashed potato-containing meals varied more than twofold. The glycaemic index (GI) of pure mashed potato was 108, whereas combined with chicken breast, rapeseed oil and salad, it was only 54. The latter GI also differed considerably from its predicted value of 103 , which was based on the individual GI of the components of the meal. The insulinaemic indices of the mashed potato-based meals varied between 94 and 148. Chicken breast in the meal increased the insulinaemic response, and rapeseed oil diminished it. However, the insulinaemic response to mashed potato with chicken breast and rapeseed oil was lower than that to mashed potato alone. In conclusion, the protein, fat and salad contents of a meal exert considerable influence on the glycaemic and insulinaemic responses to mashed potatoes. Furthermore, the estimation of the GI of a mixed meal by calculation is imprecise.
\end{abstract}

Key words: Glucose response: Glycaemic index: Insulin response: Mashed potato: Mixed meals

Postprandial hyperglycaemia and hyperinsulinaemia play an important role in the development of chronic diseases such as type 2 diabetes and $\mathrm{CVD}^{(1)}$. The concentrations of blood glucose and insulin are primarily determined by dietary carbohydrates (CHO). The term glycaemic index (GI) was introduced to classify the different sources of $\mathrm{CHO}$ and $\mathrm{CHO}$-rich foods according to their postprandial glycaemic responses ${ }^{(2)}$. Correspondingly, the insulinaemic index (II) indicates the insulinaemic response to the different $\mathrm{CHO}$ sources.

The glycaemic responses to foods, and the factors modifying them, have been studied widely in recent years. GI values for mixed meals, as well as for the whole diet, have been assessed. The main factors modifying the glycaemic responses to mixed meals are the amount of fat and protein.
This is because fat reduces the glycaemic responses by delaying gastric emptying and by enhancing the secretion of incretins $^{(3-6)}$, and protein by increasing insulin secretion ${ }^{(7)}$ and also by the slowing of gastric emptying ${ }^{(8)}$. Nevertheless, there are differing opinions on the effects of fat and protein on the glycaemic responses to mixed meals. The study of Flint et $a l .{ }^{(9)}$ has shown that the GI of mixed meals, which was calculated by using the values of published GI tables, did not predict the measured GI and that GI is more strongly correlated either with the fat or with the protein content than with the $\mathrm{CHO}$ content alone. On the other hand, Wolever et $a{ }^{(10)}$ concluded that $\mathrm{CHO}$ content and GI together explained about $90 \%$ of the variation of the glycaemic responses to mixed meals, and thus fat and protein have

Abbreviations: $\mathrm{CHO}$, carbohydrate; GI, glycaemic index; IAUC, incremental area under the curve; II, insulinaemic index. 
only negligible effects on the glycaemic responses. In addition, this same study has observed a strong correlation between the glycaemic and insulinaemic responses to mixed meals ${ }^{(10)}$. However, a recent study has illustrated that mixed meals with similar $\mathrm{CHO}$ content induce a wide range of insulin responses. Furthermore, it has also been observed that the fat content of a mixed meal had a significant inverse relationship with the insulinaemic responses ${ }^{(11)}$.

Studies have reported highly variable GI values for mashed potatoes, ranging from 71 to $106^{(12,13)}$. Added to that, it has been shown that potatoes are one of the most insulinogenic foods ${ }^{(14)}$. Glycaemic and insulinaemic responses to mashed potato are, however, modified when ingested as part of a mixed meal: the co-ingestion of fat and protein reduced the glycaemic responses and the co-ingestion of protein increased the insulinaemic responses in subjects with type 2 diabetes ${ }^{(15)}$. Moreover, a recent study has reported that the addition of various toppings to baked potato caused different decreases in the GI value ${ }^{(16)}$. There are, however, also studies showing no or increasing effect of fat on $\mathrm{GI}^{(17,18)}$. Therefore, it is important to consider the influence of macronutrients on the postprandial responses to composite meals.

We examined the glycaemic and insulinaemic responses of a mashed potato-based meal when a high-fat food (rapeseed oil) or a high-protein food (chicken breast) or fat, protein and salad together were added to the meal. Furthermore, we studied how the predicted and measured GI values of the mixed meal differed from each other.

\section{Materials and methods}

\section{Subjects}

A total of twelve healthy subjects, three men and nine women, aged 36.2 (SD 14.1) years with a BMI of $21.3(\mathrm{SD} 1.7) \mathrm{kg} / \mathrm{m}^{2}$, with a normal glucose tolerance based upon a $2 \mathrm{~h} 75 \mathrm{~g}$ oral glucose tolerance test, were recruited to voluntarily participate in the study. Of the twelve subjects, one did not complete all the test meals and was thus excluded from the analyses. The exclusion criteria were an active gastrointestinal or metabolic disease or a first-degree family history of diabetes, as well as chronic medication (oral contraceptives were allowed), and for women, in addition to pregnancy, breast-feeding, a history of gestational diabetes and polycystic ovary syndrome. The present study was conducted according to the guidelines laid down in Declaration of Helsinki, and all procedures involving human subjects were approved by the Ethics Committee of the Hospital District of Helsinki and Uusimaa. Written informed consent was obtained from all subjects.

\section{Study meals}

The subjects were given six different mashed potato-based meals in a randomised order, 1-week apart. A glucose solution was used as the reference food and was consumed twice. Each of the test meals and the reference food were given as portions, providing $50 \mathrm{~g}$ of the available $\mathrm{CHO}$, except three of the meals that included salad as portions, providing about
$54 \mathrm{~g}$ of the available $\mathrm{CHO}$. The total liquid volume of the meals was standardised to $550 \mathrm{ml}$ by adjusting the water content. The chemical composition of the study meals was analysed by VTT (Valtion Teknillinen Tutkimuskeskus (Technical Research Centre of Biotechnology), Espoo, Finland). Protein content was estimated $(\mathrm{N} \times 6.25)$ from the quantitative analysis of $\mathrm{N}$ by the Kjeldahl method ${ }^{(19)}$. Fats were determined gravimetrically by extraction with diethyl ether and petroleum ether after hydrolysis with $\operatorname{acid}^{(20)}$. Total, soluble and insoluble fibres were determined using the Asp method ${ }^{(21)}$. Free sugars (glucose, fructose, maltose, maltotriose and sucrose) were determined by the Dionex ion chromatograph system. Furthermore, the enzymatically available starch contents of the test meals and the evening meals were analysed by the method proposed by McCleary et al. ${ }^{(22)}$, using an assay kit of Megazyme (Wicklow, Republic of Ireland). The available $\mathrm{CHO}$ was calculated as the sum of the free sugars and the enzymatically available starch. The energy content of the meals varied between 1063 and $3138 \mathrm{~kJ}$. The nutrient composition of the test meals is shown in Table 1.

\section{Study protocol}

Baseline data on diet, health and lifestyle were assessed by administering a questionnaire. The food composition database and the related software at the National Institute for Health and Welfare were used to calculate the energy and nutrient intakes from a validated $\mathrm{FFQ}^{(23)}$. These intake data together with questionnaire data on physical activity at work and during leisure time were used to compose an individual's standardised meal for the evening preceding the study day. The energy content of the evening meal amounted to $15 \%$ of the daily energy needs of each individual, and the proportion of energy from the evening meal that came from $\mathrm{CHO}$ was $55 \%$. The subjects were requested to follow their usual diet throughout the study period. They were also advised to consume at least $150 \mathrm{~g}$ of $\mathrm{CHO}$ daily during the $3 \mathrm{~d}$ before the test mornings. The subjects were asked not to drink alcohol and to avoid strenuous exercise during the previous day.

The subjects were requested to fast $10-12 \mathrm{~h}$ after their standardised evening meal. To avoid exercise on the mornings when the study was conducted, they were advised to arrive by car or by public transportation. In the clinic, each subject's weight was recorded, and a baseline capillary blood sample was taken from a fingertip. Thereafter, the subject consumed the study meal within $10 \mathrm{~min}$. After the subject started to eat the meal, capillary blood samples were collected at 15, 30, 45, 60, 90 and $120 \mathrm{~min}$.

Capillary blood glucose was directly determined by using the HemoCue ${ }^{\circledR}$ Glucose 201 meter (HemoCue Limited, Espoo, Finland). The results were automatically transformed to express the plasma glucose values. The capillary blood samples $(500 \mu \mathrm{l})$ for insulin determination were collected in non-heparin-treated gel tubes and were allowed to clot at room temperature. After clotting, the samples were centrifuged ( $4000 \mathrm{~g}, 15 \mathrm{~min}$ ) within $20 \mathrm{~min}$, and then they were separated into serum and kept at $-70^{\circ} \mathrm{C}$ until being analysed. Serum insulin from the capillary samples was determined by 
Table 1. Nutrient content of the test meals

\begin{tabular}{|c|c|c|c|c|c|c|c|}
\hline & $\begin{array}{c}\mathrm{ACHO} \\
\text { (g/portion) }\end{array}$ & $\begin{array}{c}\text { Starch } \\
\text { (g/portion) }\end{array}$ & $\begin{array}{l}\text { Sugars } \\
\text { (g/portion) }\end{array}$ & $\begin{array}{l}\text { Total fibre } \\
\text { (g/portion) }\end{array}$ & $\begin{array}{c}\text { Fat } \\
\text { (g/portion) }\end{array}$ & $\begin{array}{l}\text { Protein } \\
\text { (g/portion) }\end{array}$ & $\begin{array}{c}\text { Energy } \\
\text { (kJ/portion) }\end{array}$ \\
\hline Mashed potato* & $50 \cdot 0$ & 48.5 & 1.4 & 4.7 & 3.6 & 4.7 & 1063 \\
\hline Mashed potato with oil $\dagger$ & $50 \cdot 0$ & 48.5 & 1.4 & 4.7 & $33 \cdot 6$ & 4.7 & 2173 \\
\hline $\begin{array}{l}\text { Mashed potato with } \\
\text { chicken breast }\end{array}$ & $50 \cdot 1$ & 48.5 & 1.5 & 4.7 & $10 \cdot 4$ & 34.6 & 1825 \\
\hline Mashed potato with salad§ & $53 \cdot 7$ & $49 \cdot 6$ & 4.0 & $6 \cdot 0$ & $3 \cdot 7$ & 5.9 & 1150 \\
\hline $\begin{array}{l}\text { Mashed potato with oil, } \\
\text { chicken breast and salad\| }\end{array}$ & $53 \cdot 8$ & $49 \cdot 6$ & $4 \cdot 1$ & 6.0 & $40 \cdot 5$ & $35 \cdot 8$ & 3022 \\
\hline $\begin{array}{l}\text { Mashed potato with oil, chicken } \\
\text { breast, salad and rye bread }\end{array}$ & 53.7 & $49 \cdot 6$ & 4.4 & $7 \cdot 6$ & $44 \cdot 6$ & 37.5 & 3138 \\
\hline
\end{tabular}

$\mathrm{ACHO}$, available carbohydrate.

${ }^{*}$ All the test meals contained mashed potato (Van Gogh, prepared with water and margarine). The portion size of the mashed potato was $362 \mathrm{~g}$ in all meals, except in the meal that contained rye bread. Served with $170 \mathrm{ml}$ of water and $40 \mathrm{~g}$ of cucumber.

$†$ Rapeseed oil $(30 \mathrm{~g})$ blended with mashed potato. Served with $170 \mathrm{ml}$ of water and $40 \mathrm{~g}$ of cucumber.

$\ddagger$ Chicken breast, $108 \mathrm{~g}$ (HK Ruokatalo Limited, Turku, Finland). Served with $100 \mathrm{ml}$ of water and $40 \mathrm{~g}$ of cucumber.

$\S$ The salad contained cucumber, tomato and lettuce. The portion size of the salad was $120 \mathrm{~g}$. Served with $50 \mathrm{ml}$ of water.

II Rapeseed oil $30 \mathrm{~g}+$ chicken breast $108 \mathrm{~g}+$ salad $120 \mathrm{~g}$. Served with $50 \mathrm{ml}$ of water.

I The portion size of mashed potato was $272 \mathrm{~g}+$ rapeseed oil $30 \mathrm{~g}+$ chicken breast $108 \mathrm{~g}+$ salad $120 \mathrm{~g}+$ rye bread (whole-grain rye flour $36 \%$, Vaasan Ruispalat; Vaasan \& Vaasan Limited, Helsinki, Finland) $30 \mathrm{~g}$, margarine, $80 \%$ fat (Valio Limited, Helsinki, Finland), $6 \mathrm{~g}$. Served with $90 \mathrm{ml}$ of water.

an AXSYM system, which is based on the Microparticle Enzyme Immunoassay technology (Abbot Laboratories, Abbot Park, IL, USA). During the course of the study, the inter-assay $\mathrm{CV}$ of insulin were $4.7 \%$ (low-level control, $30 \mathrm{mU} / 1(215 \cdot 25 \mathrm{pmol} / \mathrm{l}) n$ 63) and 4.8\% (high-level control, $134 \mathrm{mU} / 1(961.45 \mathrm{pmol} / \mathrm{l}) n 56)$. The sensitivity of the insulin assay was $1 \cdot 0 \mathrm{mU} / \mathrm{l}(7 \cdot 175 \mathrm{pmol} / \mathrm{l})$.

\section{Calculations and statistical analysis}

The incremental areas under the glucose and insulin response curves (IAUC), ignoring the area beneath the baseline, were calculated using the trapezoid method ${ }^{(24)}$. The GI was defined as the percentage of the plasma glucose IAUC of the study meal from that of the reference glucose solution. The same method was used to calculate the II.

\section{GI and II $=$ IAUC (test meal) $/$ IAUC $($ reference $) \times 100$.}

The predicted GI ( $\left(\mathrm{II}_{\text {pred }}\right)$ of the test meals were calculated by using the recommended method of weighting the GI of each component in the study meal.

$$
\mathrm{GI}_{\text {pred }}=\mathrm{GI}_{\mathrm{A}} \times g_{\mathrm{A}} / g+\mathrm{GI}_{\mathrm{B}} \times g_{\mathrm{B}} / g \ldots,
$$

where $\mathrm{GI}_{\mathrm{A}}$ is the GI of the component $\mathrm{A}, g_{\mathrm{A}}$ is the amount of available $\mathrm{CHO}$ in the component $\mathrm{A}(\mathrm{g})$ and $\mathrm{g}$ is the total amount of available $\mathrm{CHO}$ measured in $\mathrm{g}$ in the study meal. For rye bread, we used the measured GI value of our own laboratory, GI $=77^{(25)}$. However, there were no GI values for salad vegetables ${ }^{(12)}$. As proxy, we used the unpublished value for raw carrots $(\mathrm{GI}=39)$, which was assessed in our laboratory ${ }^{(26)}$.

Excluded from the analyses were the $2 \mathrm{~h}$ insulin curves that included one or more strongly or three or more mildly haemolysed serum samples. The data were analysed with SAS software (version 8.2; SAS Institute, Cary, NC, USA). All results are expressed as means with their standard errors, and the statistical significance of difference was assessed by applying the non-parametric Wilcoxon test with Bonferroni's corrections. The $P$ values of $<0.05$ were considered to be statistically significant.

\section{Results}

Of the study meals, the highest increase in glucose at $30 \mathrm{~min}$ was produced by the consumption of mashed potato alone and with salad. The glucose concentrations at $120 \mathrm{~min}$ after these meals fell below the baseline levels (Fig. 1). The incremental peaks and areas under the curves were the highest, resulting in a GI value of 108 for both (Table 2). Mashed potato produced high insulinaemic responses, resulting in an insulin index of 118, whereas the insulin index for mashed potato with salad was slightly lower, 105 (Table 3).

Ingestion of mashed potato with rapeseed oil slowed down the initial glucose increase, the value being $1.6 \mathrm{mmol} / 1$ lower at $30 \mathrm{~min}$ than that for mashed potato alone $(P=0 \cdot 08$; Fig. 1 and Table 2). Furthermore, the addition of oil reduced the IAUC, resulting in a GI value of 71 . The II for mashed potato with oil was 97 (Table 3).

The addition of a protein source, i.e. chicken breast, to a mashed potato meal produced a $1.2 \mathrm{mmol} / 1$ smaller increase in glucose at $30 \mathrm{~min}$ than mashed potato alone $(P=0.04)$. The protein source provided a $42 \%$ reduction in the IAUC $(P=0.08$; Table 2$)$, resulting in a GI value of $64(P=0.05)$, whereas it increased the insulin response, resulting in the highest II value of 148 (Table 3).

The co-ingestion of oil, chicken breast and salad with mashed potato significantly diminished the glycaemic response, and the result was a low GI value of $54(P=0.03$; Table 2). When part of the available $\mathrm{CHO}$ of mashed potato was substituted with that of rye bread, the IAUC was moderately increased, resulting in the GI value of $65(P=0 \cdot 21)$. When oil, chicken breast and salad were simultaneously eaten with mashed potato, the II was 106. In addition, the meal containing rye bread produced the lowest II value of 94 (Table 3). 


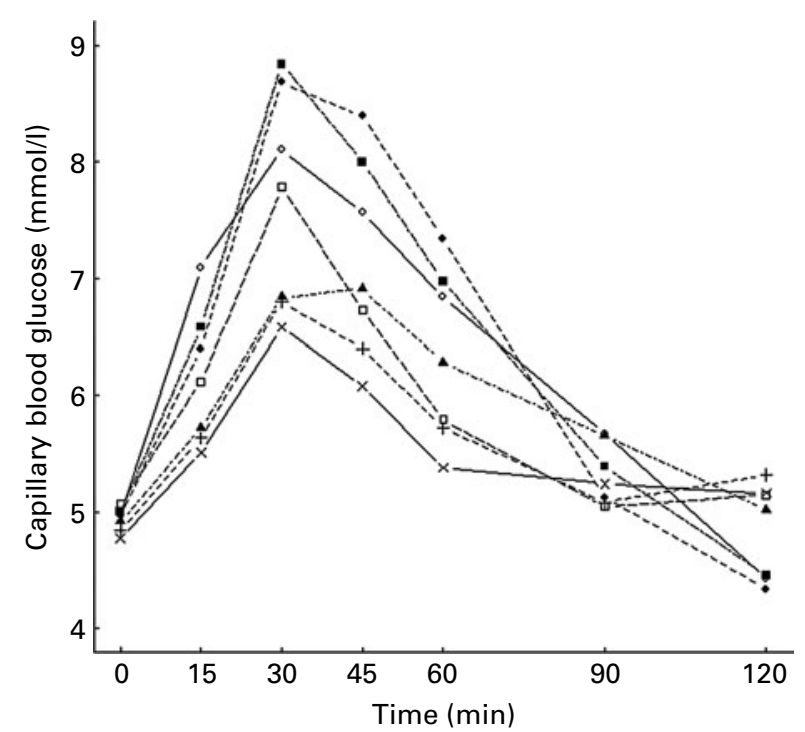

Fig. 1. Mean changes in plasma glucose in healthy subjects $(n 11)$ after the consumption of the study meals. $\diamond$, Glucose; $\diamond$, mashed potato; $\Delta$, mashed potato with oil; $\square$, mashed potato with chicken breast; - mashed potato with salad; $\times$, mashed potato with oil, chicken breast and salad; + , mashed potato with oil, chicken breast, salad and rye bread.

The GI values of the study meals ranged from 54 to 108 . However, the predicted GI values varied only from 96 to 108 (Table 2). The consumption of chicken breast with mashed potato resulted in a clearly lower GI value, which was $40 \%$ lower than the predicted GI value, $108 v .64$ $(P=0 \cdot 048)$. Moreover, oil in the mixed meal diminished the GI values by $34 \%, 108 v .71(P=0 \cdot 06)$.

\section{Discussion}

The present study shows that by adding a fat component or a protein component either alone or together to a mashed potato-based meal results in a decrease in glycaemic responses. This highlights the problems encountered when predicting the GI values of mixed meals. The protein component of the mixed meal evoked the largest insulinaemic responses and markedly increased the II of the mixed meal containing protein. However, introducing fat into the meal decreased the effect of protein on the insulinaemic responses. In recently published international GI tables ${ }^{(12)}$, high GI values have been reported for mashed potatoes, varying between 71 and 102. In addition, one previous study has measured an even higher GI value, i.e. 106, for mashed potatoes $^{(13)}$. Some studies have established that fat ingested with potato lowers glycaemic responses ${ }^{(3,27,28)}$. On the other hand, no effect of fat was observed on the glycaemic responses in subjects with type 2 diabetes ${ }^{(17)}$. Furthermore, one study observed that when healthy subjects co-ingested $15 \mathrm{~g}$ of sunflower oil with boiled potatoes, an elevated GI was obtained ${ }^{(18)}$. In the present study, we found that the addition of $30 \mathrm{~g}$ of rapeseed oil into mashed potatoes markedly reduced the peak rise of blood glucose and resulted in a 37 unit smaller GI value than for the consumption of mashed potato alone. This finding is consistent with previous studies $^{(16,29)}$. Moreover, according to MacIntosh et al. ${ }^{(29)}$, the different degrees of saturation of added fat did not affect the glycaemic responses. For example, dietary fat and protein were associated inversely with $\mathrm{GI}^{(2)}$; protein had a two- to threefold greater reducing gram-for-gram effect on the glycaemic responses than $\mathrm{fat}^{(30)}$. In the present study, the addition of $30 \mathrm{~g}$ protein reduced the glycaemic response slightly more than the addition of $30 \mathrm{~g}$ fat. Furthermore, the present results demonstrate that the co-ingestion of fat and protein with mashed potato markedly decreased the glycaemic responses and the GI values, which is consistent with the results of a previous study ${ }^{(15)}$.

In the present study, the $\mathrm{CHO}$ content of all meals was kept constant at $50 \mathrm{~g}$, except for the meals with salad. Mashed potato with salad, mashed potato with oil, chicken breast and salad, and mashed potato with oil, chicken breast, salad and rye contained about $4 \mathrm{~g}$ more of the available $\mathrm{CHO}$ than the other meals. However, $4 \mathrm{~g}$ more of the available $\mathrm{CHO}$

Table 2. Fasting blood glucose values, incremental peaks and incremental areas under the curves (IAUC) of the capillary blood glucose and glycaemic index (GI) values in healthy subjects after the study meals

(Mean values with their standard errors, $n$ 11)

\begin{tabular}{|c|c|c|c|c|c|c|c|c|c|}
\hline & \multicolumn{2}{|c|}{$\begin{array}{l}\text { Fasting blood } \\
\text { glucose } \\
\text { (mmol/l) }\end{array}$} & \multicolumn{2}{|c|}{$\begin{array}{c}\text { Incremental } \\
\text { peak of } \\
\text { glucose }(\mathrm{mmol} / \mathrm{l})\end{array}$} & \multicolumn{2}{|c|}{$\begin{array}{c}\text { IAUC } \\
(\mathrm{mmol} \times \min \text { per } \mathrm{l})\end{array}$} & \multirow[b]{2}{*}{ Predicted Gl } & \multicolumn{2}{|c|}{ Measured GI } \\
\hline & Mean & SE & Mean & SE & Mean & SE & & Mean & SE \\
\hline Glucose solution & $5 \cdot 0$ & 0.1 & $4 \cdot 1$ & 0.4 & 190 & $19 \cdot 1$ & & & \\
\hline Mashed potato & $5 \cdot 0$ & $0 \cdot 1$ & $4 \cdot 0$ & 0.3 & 197 & $28 \cdot 2$ & & 108 & $14 \cdot 4$ \\
\hline Mashed potato with oil & $4 \cdot 9$ & $0 \cdot 1$ & $2 \cdot 4$ & 0.3 & 136 & $22 \cdot 4$ & 108 & 71 & $9 \cdot 5$ \\
\hline Mashed potato with chicken breast & $5 \cdot 0$ & $0 \cdot 1$ & $2 \cdot 8^{\star}$ & 0.3 & 113 & $16 \cdot 3$ & 108 & $64 \dagger$ & $10 \cdot 0$ \\
\hline Mashed potato with salad & $5 \cdot 0$ & 0.1 & 4.0 & 0.3 & 189 & $22 \cdot 1$ & 103 & 108 & 11.5 \\
\hline $\begin{array}{l}\text { Mashed potato with oil, chicken } \\
\text { breast and salad }\end{array}$ & $4 \cdot 8$ & 0.1 & $2 \cdot 0^{*}$ & 0.2 & $96 \ddagger$ & 12.5 & 103 & $54 †$ & 6.5 \\
\hline $\begin{array}{l}\text { Mashed potato with oil, chicken } \\
\text { breast, salad and rye bread }\end{array}$ & $4 \cdot 8$ & 0.1 & $2 \cdot 2^{\star}$ & 0.3 & 105 & $16 \cdot 7$ & 96 & 65 & 11.4 \\
\hline
\end{tabular}

* Mean values were significantly different from those of the incremental peak of glucose of mashed potato: $P<0.05$.

† Mean values were significantly different from those of the predicted GI values: $P<0.05$.

$\ddagger$ Mean value was significantly different from that of the IAUC of mashed potato: $P<0.05$. 
Table 3. Fasting blood insulin values, incremental peaks of insulin and insulinaemic indices (II) in healthy subjects after the study meals (Mean values with their standard errors and number of individuals)

\begin{tabular}{|c|c|c|c|c|c|c|c|c|c|}
\hline & \multicolumn{3}{|c|}{$\begin{array}{l}\text { Fasting blood } \\
\text { insulin (mU/l) }\end{array}$} & \multicolumn{3}{|c|}{$\begin{array}{l}\text { Incremental peak } \\
\text { of insulin (mU/l) }\end{array}$} & \multicolumn{3}{|c|}{ II } \\
\hline & $n$ & Mean & SE & $n$ & Mean & SE & $n$ & Mean & SE \\
\hline Glucose solution & 11 & 3.4 & 0.4 & 11 & 35.5 & $5 \cdot 7$ & & & \\
\hline Mashed potato & 11 & $4 \cdot 3$ & 0.9 & 11 & 44.9 & $10 \cdot 9$ & 8 & 118 & $14 \cdot 2$ \\
\hline Mashed potato with oil & 11 & $3 \cdot 8$ & 0.5 & 11 & $25 \cdot 6$ & $4 \cdot 2$ & 8 & 97 & $16 \cdot 2$ \\
\hline Mashed potato with chicken breast & 11 & $4 \cdot 3$ & 0.6 & 11 & $48 \cdot 2$ & $13 \cdot 8$ & 8 & 148 & $27 \cdot 6$ \\
\hline Mashed potato with salad & 11 & 4.0 & 0.5 & 11 & $36 \cdot 7$ & $9 \cdot 3$ & 8 & 105 & $9 \cdot 9$ \\
\hline Mashed potato with oil, chicken breast and salad & 11 & 3.9 & 0.7 & 11 & 34.4 & 7.5 & 7 & 106 & $10 \cdot 3$ \\
\hline Mashed potato with oil, chicken breast, salad and rye bread & 11 & $3 \cdot 2$ & 0.7 & 11 & $32 \cdot 0$ & 7.4 & 7 & 94 & $15 \cdot 0$ \\
\hline
\end{tabular}

did not affect the glycaemic responses. Hence, the differences in the GI values of the meals were due to the fat or protein content of these meals. This observation is supported by previous findings ${ }^{(9,16)}$.

Previous studies have provided divergent results about the use of the GI of the different $\mathrm{CHO}$ sources to determine the glycaemic responses of mixed meals ${ }^{(9,10)}$. For instance, the study by Flint et al. ${ }^{(9)}$ concluded that it was not reliable to predict the GI value of mixed meals by using literature-based GI values only, and that in fact, the GI of the mixed meals was more strongly correlated either with the fat or the protein content than with the $\mathrm{CHO}$ content alone. Wolever et al. ${ }^{(10)}$, again, found only negligible effects of protein and fat on the mean glycaemic responses to the mixed meals, and thus CHO explained about $90 \%$ of the glycaemic response. However, in the present study, the predicted GI values of the mixed meals were not the same as the measured GI values of the meals because the GI value decreased remarkably after the addition of oil and/or protein to the mashed potato meal. This finding is similar to that of Flint et al. ${ }^{(9)}$.

The results of the present study illustrate that the insulin responses to mashed potato-based meals were high. This finding is consistent with previous observations, which have classified potato as one of the most insulinogenic foods ${ }^{(14)}$. However, our findings demonstrated that adding fat or protein to the meal substantially modified the insulinaemic responses to mashed potato. Previous studies have shown that protein has an insulinogenic effect ${ }^{(15,31,32)}$, while fat reduces insulin responses $^{(5,15,17)}$ when the source of the available $\mathrm{CHO}$ was potatoes. Although both fat and protein slow gastric emptying and thereby reducing postprandial glycaemia, it seems that the reduced glycaemia due to protein is more likely to be explained by the enhanced insulin secretion ${ }^{(4,33)}$. In the present study, the insulinaemic response was moderately reduced when $120 \mathrm{~g}$ of salad were added to the mashed potato meal. When the mashed potato meal included rapeseed oil, chicken breast and salad, the insulin response was smaller than that for mashed potato alone. Thus, oil and salad were able to overcome the strong increase in insulin response that was induced by the protein source alone. Another important factor is that the higher energy content of the meal slows gastric emptying ${ }^{(34)}$, which may partly explain this finding.

\section{Conclusion}

We conclude that both fat and protein have an independent decreasing effect on the glycaemic responses to mashed potatoes in healthy subjects. The estimation of the GI of a mixed meal by calculation is imprecise when the meal contains fat and/or protein. The insulin response and the II to a mixed meal depend on the fat, protein and salad content of the meal. Since a mashed potato-based meal including a high-fat or high-protein food induces a substantially lower glycaemic response than mashed potatoes alone, there is no reason for recommendations to avoid eating potatoes. The nutrient content of potatoes is favourable; therefore, using potatoes moderately as a part of a meal should be encouraged.

\section{Acknowledgements}

We warmly thank the volunteers for taking the time to participate in the postprandial study. We extend our appreciation to Heikki Pakkala and Jukka Lauronen for assisting with the technical aspects of the study, and Laura Lund, Pia Mustonen and Raija Nevala for laboratory assistance. The present study was supported by the Ministry of Agriculture and Forestry, the Academy of Finland (grant no. 111420), the Juho Vainio Foundation, the Finnish Cultural Foundation and the Finnish Graduate School on Applied Bioscience: Bioengineering, Food and Nutrition, Environment. The contribution of each author was as follows: K. A. H., J. V., J. G. E. and L. M. V. contributed to the conception and design of the study; K. A. H and L. M. V. carried out the postprandial studies; J. E. S. was responsible for the analysis of the blood samples; H. K. S. carried out the statistical analysis; K. A. H. wrote the first draft of the manuscript; K. A. H., J. V., J. G. E. and L. M. V. participated in the writing of the final draft of the manuscript; K. A. H., J. V., J. G. E., H. K. S., J. E. S. and L. M. V. were responsible for the final manuscript. There are no conflicts of interest.

\section{References}

1. Ludwig DS (2002) The glycemic index: physiological mechanisms relating to obesity, diabetes, and cardiovascular disease. JAMA 287, 2414-2423.

2. Jenkins DJ, Wolever TM, Taylor RH, et al. (1981) Glycemic index of foods: a physiological basis for carbohydrate exchange. Am J Clin Nutr 34, 362-366. 
3. Collier G \& O'Dea K (1983) The effect of coingestion of fat on the glucose, insulin, and gastric inhibitory polypeptide responses to carbohydrate and protein. Am J Clin Nutr 37, 941-944.

4. Gentilcore D, Chaikomin R, Jones KL, et al. (2006) Effects of fat on gastric emptying of and the glycemic, insulin, and incretin responses to a carbohydrate meal in type 2 diabetes. J Clin Endocrinol Metab 91, 2062-2067.

5. Welch IM, Bruce C, Hill SE, et al. (1987) Duodenal and ileal lipid suppresses postprandial blood glucose and insulin responses in man: possible implications for the dietary management of diabetes mellitus. Clin Sci (Lond) 72, 209-216.

6. Deane AM, Nguyen NQ, Stevens JE, et al. (2010) Endogenous glucagon-like peptide-1 slows gastric emptying in healthy subjects, attenuating postprandial glycemia. J Clin Endocrinol Metab 95, 215-221.

7. Nuttall FQ, Mooradian AD, Gannon MC, et al. (1984) Effect of protein ingestion on the glucose and insulin response to a standardized oral glucose load. Diabetes Care 7, 465-470.

8. Karamanlis A, Chaikomin R, Doran S, et al. (2007) Effects of protein on glycemic and incretin responses and gastric emptying after oral glucose in healthy subjects. Am J Clin Nutr 86, 1364-1368.

9. Flint A, Moller BK, Raben A, et al. (2004) The use of glycaemic index tables to predict glycaemic index of composite breakfast meals. Br J Nutr 91, 979-989.

10. Wolever TM, Yang M, Zeng XY, et al. (2006) Food glycemic index, as given in glycemic index tables, is a significant determinant of glycemic responses elicited by composite breakfast meals. Am J Clin Nutr 83, 1306-1312.

11. Bao J, de Jong V, Atkinson F, et al. (2009) Food insulin index: physiologic basis for predicting insulin demand evoked by composite meals. Am J Clin Nutr 90, 986-992.

12. Atkinson FS, Foster-Powell K \& Brand-Miller JC (2008) International tables of glycemic index and glycemic load values: 2008. Diabetes Care 31, 2281-2283.

13. Tahvonen R, Hietanen RM, Sihvonen J, et al. (2006) Influence of different processing methods on the glycemic index of potato (Nicola). J Food Compos Anal 19, 372-378.

14. Holt SH, Miller JC \& Petocz P (1997) An insulin index of foods: the insulin demand generated by $1000-\mathrm{kJ}$ portions of common foods. Am J Clin Nutr 66, 1264-1276.

15. Gulliford MC, Bicknell EJ \& Scarpello JH (1989) Differential effect of protein and fat ingestion on blood glucose responses to high- and low-glycemic-index carbohydrates in noninsulin-dependent diabetic subjects. Am J Clin Nutr 50, 773-777.

16. Henry CJ, Lightowler HJ, Kendall FL, et al. (2006) The impact of addition of toppings/fillings on the glycaemic response to commonly consumed carbohydrate foods. Eur J Clin Nutr 60, 763-769.

17. Gannon MC, Ercan N, Westphal SA, et al. (1993) Effect of added fat on plasma glucose and insulin response to ingested potato in individuals with NIDDM. Diabetes Care 16, 874-880.

18. Leeman M, Östman E \& Björck I (2008) Glycaemic and satiating properties of potato products. Eur J Clin Nutr 62, 87-95.

19. Eagan H, Kirk RS \& Sawyer R (1981) Pearson's Chemical Analysis of Foods. Edinburgh/London/Melbourne/NewYork: Church Hill Livingstone.
20. AOAC International (1995) Official Methods of Analysis of AOAC International, 922.06, 16th ed. Arlington, VA: AOAC International.

21. Asp NG, Johansson CG, Hallmer H, et al. (1983) Rapid enzymic assay of insoluble and soluble dietary fiber. $J$ Agric Food Chem 31, 476-482.

22. McCleary BV, Gibson TS \& Mugford DC (1997) Measurement of total starch in cereal products by amyloglucosidase $-\alpha$ amylase method: collaborative study. $J A O A C$ Int $\mathbf{8 0}$, 571-579.

23. Paalanen L, Männistö S, Virtanen MJ, et al. (2006) Validity of a food frequency questionnaire varied by age and body mass index. J Clin Epidemiol 59, 994-1001.

24. Food and Agriculture Organization (1998) Carbohydrates in Human Nutrition. Report of a Joint FAO/WHO Expert Consultation, 14-18 April 1997, Rome, Italy. FAO Food Nutrition Paper No. 66. Rome: FAO.

25. Hätönen KA, Similä ME, Virtamo JR, et al. (2006) Methodologic considerations in the measurement of glycemic index: glycemic response to rye bread, oatmeal porridge, and mashed potato. Am J Clin Nutr 84, 1055-1061.

26. Similä ME, Valsta LM, Virtanen MJ, et al. (2009) Glycaemic index database for the epidemiological Alpha-Tocopherol, Beta-Carotene Cancer Prevention (ATBC) Study. Br J Nutr 101, 1400-1405.

27. Ercan N, Gannon MC \& Nuttall FQ (1994) Effect of added fat on the plasma glucose and insulin response to ingested potato given in various combinations as two meals in normal individuals. Diabetes Care 17, 1453-1459.

28. Gannon MC, Nuttall FQ, Westphal SA, et al. (1993) The effect of fat and carbohydrate on plasma glucose, insulin, C-peptide, and triglycerides in normal male subjects. J Am Coll Nutr 12, 36-41.

29. MacIntosh CG, Holt SH \& Brand-Miller JC (2003) The degree of fat saturation does not alter glycemic, insulinemic or satiety responses to a starchy staple in healthy men. $J$ Nutr 133, 2577-2580.

30. Moghaddam E, Vogt JA \& Wolever TM (2006) The effects of fat and protein on glycemic responses in nondiabetic humans vary with waist circumference, fasting plasma insulin, and dietary fiber intake. J Nutr 136, 2506-2511.

31. Bornet FR, Costagliola D, Rizkalla SW, et al. (1987) Insulinemic and glycemic indexes of six starch-rich foods taken alone and in a mixed meal by type 2 diabetics. Am J Clin Nutr 45, 588-595.

32. Gannon MC, Nuttall FQ, Neil BJ, et al. (1988) The insulin and glucose responses to meals of glucose plus various proteins in type II diabetic subjects. Metabolism 37, 1081-1088.

33. Ma J, Stevens JE, Cukier K, et al. (2009) Effects of a protein preload on gastric emptying, glycemia, and gut hormones after a carbohydrate meal in diet-controlled type 2 diabetes. Diabetes Care 32, 1600-1602.

34. Kwiatek MA, Menne D, Steingoetter A, et al. (2009) Effect of meal volume and calorie load on postprandial gastric function and emptying: studies under physiological conditions by combined fiber-optic pressure measurement and MRI. Am J Physiol Gastrointest Liver Physiol 297, G894-G901. 